\title{
KEDUDUKAN HUKUM TANAH ADAT PELABA PURA SEBAGAI TANAH ULAYAT DI DESA TAMPAKSIRING KABUPATEN GIANYAR
}

\author{
Ida Bagus Nyoman Trisya Andika, I Wayan Wesna Astara, I Putu Gede Seputra \\ Fakultas Hukum Universitas Warmadewa, Denpasar-Bali, Indonesia
}

\begin{abstract}
Abstrak
Bali sebagai salah satu Provinsi yang adatnya masih kental juga memiliki beberapa aturan adat (hukum adat) yang mengikat. Kedudukan tanah ulayat masih kurang mendapat perlindungan hukum. Masih terdapat banyak warga desa yang tidak melakukan pengurusan tanah pura atau dalam status tanah ulayat menjadi sah dimata hukum. Penelitian ini bertujuan untuk mengetahui eksistensi tanah adat pelaba pura sebagai tanah ulayat di Desa Tampaksiring kabupaten Gianyar secara hukum agraria dan menganalisis implementasi kedudukan hukum terhadap tanah pelaba pura di Desa Tampaksiring Kabupaten Gianyar. Penelitian ini menggunakan penelitian hukum empiris dengan pendekatan perundang-undangan. Adapun sumber hukum adalah bahan hukum primer yaitu menggunakan bahan hukum yang dikaji menggunakan peraturan yang berlaku khusus sedangkan bahan hukum sekunder berpedoman pada literatur, artikel, jurnal serta terkait dengan permasalahan. Hasil penelitian menunjukkan bahwa Proses penyelesaian sengketa pensertifikatan tanah pelaba pura di Desa Tampaksiring Kabupaten Gianyar adalah dengan menggunakan sanksi delik adat yaitu dengan melakukan pemagaran terhadap tanah tersebut sesuai hasil dari paruman adat yang telah dilaksanakan. Akhirnya tanah tersebut diserahkan kembali ke pura secara suka rela. Kedudukan hukum terhadap tanah pelaba pura di Desa Tampaksiring merupakan hal penting yang harus diperhatikan karena masih banyak kasus yang sangketa yang terjadi di masyarakat Bali khusunya di Desa Tampaksiring. Pada sengketa tanah pelaba pura di Tampaksiring mengacu pada hukum adat dimana sanksi yang diberikan pada pelaku pensertifikatan tanah merupakan sanksi yang yang telah disepakati dan diatur dalam hukum adat setempat.
\end{abstract}

Kata Kunci: Tanah Ulayat; Perlindungan Hukum; Delik Adat

\begin{abstract}
Bali as a province with strong customs also has several binding customary laws. The status of ulayat land still lacks legal protection. There are still many villagers who do not take care of the temple land or in the status of their ulayat land which is legal. This study aims to determine the existence of pelaba pura customary land as communal land in the village of Tampaksiring, Gianyar district by law of agrarian law and to analyze the implementation of the legal position of the pelaba pura land in Tampaksiring Village, Gianyar Regency. This study uses empirical legal research with a statutory approach. The source of law is primary legal materials, namely using legal materials that are studied using specifically applicable regulations, while secondary legal materials are based on literature, articles, journals and related to problems. The results showed that the process of resolving the land certification of pelaba pura land in Tampaksiring Village, Gianyar Regency was by using the customary offense sanction, namely by fencing the land according to the results of the customary paruman that had been implemented. Finally, the land was voluntarily handed back to the temple. The legal position of the temple's pelaba land in Tampaksiring Village is an important matter that must be considered because there are still many suspected cases that have occurred in Balinese society, especially in Tampaksiring Village. In land disputes, the temples in Tampaksiring refer to customary law where the sanctions imposed on land certifiers are sanctions that have been agreed upon and regulated in local customary law.
\end{abstract}

Keywords: Ulayat Land; Legal Protection; Customary Delik

\section{PENDAHULUAN}

Keberadaan hukum adat eksistensinya menjadi salah satu hukum yang telah diaku pada masyarakat serta budaya yang ada di Indonesia yang tercantum pada UUD Republik Indonesia Pada Tahun 1945. Berdasarkan SK Menteri dalam Negeri dan Kepala Badan Pertanahan Nasional dengan Nomor SK 520.1/2252, Tanggal 27 Juli 2000 mengenai penunjukkan objek hukum yaitu pura yang dijadikan salah satu badan hukum yang bersifat keagamaan dimana mendapat hak milik dari tanah. Dengan SK tersebut pura-pura yang tersebar pada wilayah Indonesia bisa menguasai atas tanah dengan status sebagai hak milik. Selanjutnay dikuatkan oleh Perda Nomor 4 Tahun 2019 tentang Desa 
Adat. Hukum adat di Indonesia juga mempengaruhi berbagai aspek hukum lainnya seperti hukum pertanahan. Objek hukum tanah adalah hak penguasaan atas tanah.

Kelahiran Undang-Undang No 5 Tahun 1960 Mengenai Pokok Agraria (UUPA) merupakan salah satu upaya yang ditujukan untuk kejelasan hukum pertanahan di Indonesia agar tidak terjadi perpecahan wilayah, ras suku dan budaya Indonesia yang mengganggu persatuan bangsa (H, 2012). Tanah ulayat masyarakat adat termasuk juga pada masyarakat di Bali merupakan suatu bentuk wilayah hukum yang ada pada masyarakat adat dimana kepemilikannya dapat dipegang oleh masyarakat yang tinggal disana yang dipimpin oleh tokoh adat (Arba, 2012). Permasalahan yang terjadi adalah dimana dalam tataran law in action, kedudukan tanah ulayat bila berhadapan dengan kepentingan pembangunan masih kurang mendapatkan perlindungan hukum. Sebagai contoh kasus yang terjadi di Bali yaitu kasus sertifikatkan tanah pelaba pura diam-diam di Manukaya Gianyar, Tampaksiring yang berawal dari peminjaman lahan yang berujung pada pensertifikatan tanah pelaba pura tersebut menjadi milik pribadi.

Isu yang terjadi adalah dimana masih terdapat banyak warga desa yang tidak melakukan pengurusan tanah pura atau dalam status tanah ulayat menjadi sah dimata hukum. Masih terdapat beberapa daerah seperti di daerah Tampaksiring Kabupaten Gianyar, dimana tanah ulayat tersebut menjadi sengketa setelah beberapa pihak mengklaim tanah ulayat tersebut sebagai tanah milik pribadi dengan adanya sertifikat kepemilikan tanah. Merujuk pada pemaparan latar belakang, maka peneliti tertarik untuk membahas mengenai "Kedudukan Hukum Tanah Adat Pelaba Pura Sebagai Tanah Ulayat di Desa Tampaksiring Kabupaten Gianyar". Menurut Suwitra, (2010) Terjadinya konversi tanah-tanah adat menjadi tanah individu penuh berdampak pada hilangnya status "ayahan" yang melekati tanah adat tersebut. Agar tidak menimbulkan masalah untuk tanah-tanah desa yang sudah diserahkan penguasaannya kepada perseorangan krama desa (tanah pekarangan desa dan ayahan desa) seharusnya perlu dilakukan secara hati-hati (Sudantra, 2018b). Berdasarkan latar belakang masalah tersebut dilakukan penlitian yang bertujuan untuk mengkaji eksistensi tanah adat pelaba pura sebagai tanah ulayat di Desa Tampaksiring kabupaten Gianyar secara hukum agraria dan menganalisis implementasi kedudukan hukum terhadap tanah pelaba pura di Desa Tampaksiring kabupaten Gianyar

\section{METODE PENELITIAN}

Penelitian ini menggunakan penelitian empiris yaitu peneliti turun lapangan melakukan observasi dan kegiatan wawancara serta mengumpulkan data sehingga memperoleh hasil yang sesuai fakta dan akurat. Pendekatan yang digunakan adalah pendekatan perundang-undangan. Adapun sumber hukum yang digunakan yaitu bahan hukum primer yaitu menggunakan bahan hukum yang dikaji menggunakan peraturan yang berlaku khusus sedangkan bahan hukum sekunder berpedoman pada literatur, artikel, jurnal serta terkait dengan permasalahan. Teknik dalam pengumpulan bahan hukum dilakukan dengan cara teknik wawancara yaitu dengan melakukan proses tanya jawab dengan pihak yang terkait secara langsung maupun tidak langsung sebagai penunjang data-data yang diperlukan. Setelah bahan hukum tersebut terkumpul kemudian menafsirkan atau menginterprestasikan secara sistematis maupun terstruktur menggunakan argument yang disertai dengan solusi dari permasalahan yang ada yang kemudian dianalisis secara deskriptif kualitatif (Bambang, 2002).

\section{HASIL DAN PEMBAHASAN}

\section{Eksistensi Tanah Adat Pelaba Pura sebagai Tanah Ulayat di Desa Tampaksirin Kabupaten} Gianyar Secara Hukum Agraria

Undang-Undang Pokok Agrarian No. 5 Tahun 1960 Pasal 2 Ayat 2 menyebutkan bahwa Hak Ulayat pada kepustakaan hukum adat yaitu (beschikkingsrecht). Hak Ulayat dikatakan yuridis dimana hak ulayat berupa hak yang merupakan ciri khas dari masyarakat yang memiliki hukum adat. Hak ulayat ini berisi kekuasaan yang dimiliki atas tanah dan seisinya yang telah diakui sebagai hak ulayat yang diatur dan diurus oleh pengurus adat (Sudantra, 2018a). Adapun wewenang yang dimiliki pada Hak Ulayat yaitu untuk:

1. Mengurus tanahnya untuk dijadikan sebagai lahan pertanian pemukiman dan lain sebagainya

2. Membatasi kegiatan yang dapat mengeksploitasi tanah ulayat dan menjelaskan kejelasan hubungan antara tanah tersebut dengan masyarakat. 
3. Menetapkan bahwa tanah ulayat memiliki kejelasan hukum yang mana tidak boleh sembarang orang dapat menguasai tanah ulayat dan memberikan sanksi adat dan juga melaporkan kepada pihak yang berwajib

Ada beberapa tanah adat di Bali, tanah milik adat disebut dengan "Tanah Desa" ataupun "Tanah Druwe" yang berarti tanah yang dimiliki dan dikuasai yang didapat baik dengan cara pembelian atau usaha lainnya serta dikuasai oleh desa adat. Tanah memiliki peran yang sangat penting dalam hukum adat. Hal tersebut diakibatkan oleh pertama yaitu sifat tanah yang memberikan keuntungan kepada pemiliknya karena tanah merupakan harta kekayaan. Sedangka dari faktanya yaitu tanah merupakan salah satu dasar untuk orang membangun rumah tinggal selain juga sebagai tempat dikuburkannya masyarakat yang mendiami suatu wilayah (S. Hendriatiningsih, A Budhiarta, 2008).

Maka berdasarkan tanah adat dapat dikategorikan sesuai status serta fungsinya yaitu sebagai berikut:

1. Tanah pekarangan desa (PKD) adalah tanah yang dimiliki oleh warga desa untuk dijadikan tempat bermukim atau tempat tingga

2. Tanah ayahan desa yaitu tanah digarap oleh desa yang pada umumnya berupa lahan pertanian yang dapat menghasilkan hasil pertanian dan dibagikan kepada warga desa

3. Tanah laba pura adalah tanah yang terikat pada suatu pura ataupun lebih yang memiliki nilai hasil seperti tanah pertanian atau perkebunan yang dapat dijadikan salah satu sumber penghasilan

4. Tanah druwe desa adalah tanah yang dimiliki oleh desa dan digunakan untuk kepentingan desa seperti dijadikan lapangan, kuburan, pasar dan lain sebagainya.

Tanah pelaba pura yaitu sebagian tanah milik desa yang digunakan untuk menunjang kegiatan upacara keagamaan di Pura. Tanah pelaba pura dipergunakan sebagai salah satu sumber pemenuhan kebutuhan untuk pura saat akan dilaksanakannya upacara di suatu pura yang bersangkutan. Saat ini terdapat beberapa masalah yang dihadapi oleh tanah milik pura. Permasalahan-permasalahan tersebut adalah:

a. Masih tanah yang merupakan milik pura namun kenyataan yang ada di lapangan tanah tersebut dikuasai oleh pihak lain

b. Kepastian dan perlindungan hukum masih banyak belum dimiliki tanah pelaba karena belum didaftarkan sehingga tanah-tanah

c. Pada saat ini sekitaran tanah pelaba pura dijadikan bangunan yang membuat tanah pelaba pura tidak dapat ditanami atau kurangnya perhatian terhadap tanah pelaba pura.

Masih banyak lagi kasus yang berkaitan dengan tanah pelaba pura sebagai tanah ulayat sehingga perlu adanya perlindungan dan kepastian hukum untuk mencegah terjadinya sangketa. Perlindungan hukum didefiniskan sebagai perlindungan yang sudah memiliki kekuatan hukum yang ditujukan untuk melindungi subyek hukum baik secara tertulis maupun tidak tertulis. Dengan kata lain adanya perlindungan hukum merupakan salah satu upaya yang dilakukan oleh pemerintah agar subyek hukum memiliki jaminan hukum atau kepastian hukukm dan memberikan keamanan bagi warga Negara karna memiliki status hukum yang pasti serta memiliki sanksi bagi yang melangga (Soeroso, 2006).

\section{Implementasi Kedudukan Hukum terhadap Tanah Elaba Pura di Desa Tampaksiring Kabupaten Gianyar}

Eksistensi tanah pelaba pura telah memiliki dasar hukum yang kuat yaitu PP No. 38 Tahun 1963 Menerangkan bahwa badan hukum boleh memiliki kepemilikan atas tanah. dan dipertegas lagi oleh Surat Menteri dalam Negeri SK/556/DJA/1986 yaitu tentang Pura yang ditunjuk sebagai badan hukum bersifat keagamaan dimana telah memiliki hak kepemilikan terhadap keberadaan tanah. Sehingga pura yang sebagai badan hukum keagamaan telah dapat mendaftarkan sesuai peraturan yang berlaku hal ini bertujuan agar tanah pelaba pura mendapatkan kepastian serta perlindungan hukum. Proses pembuatan peraturan perundang-undangan, politik hukum memiliki peranan sangat penting. Pertama, sebagai landasan dibutuhkannya penataan suatau aturan. Kedua, untuk menentukan hal yang akan di terjemahkan dalam kalimat perumusan pasal (Harsono, 2003).

Para pengurus pura dapat melakukan berbagai upaya untuk menjaga status kepemilikan tanah pura yaitu dengan mengambil tindakan seperti pendataan terhadap tanah yang dimiliki oleh pura dan kemudian mendaftarkannya. Pasal 19 UUPA Pasal 2 Ayat 2 menjelaskan bahwa adanya kepastian hukum terhadap tanah pura sehingga tanah pura perlu didaftarkan yang sesuai aturan yang 
telah ditetapkan (Djamali Abdoel, 2013). Sebagaimana kita ketahui Undang-Undang No 5 Tahun 1960 tentang Pokok Agraria yang menerangkan tentang fungsi-fungsi dari adanya hak terhadap suatu tanah ataupun jaminan dimana Indonesia juga memiliki hukum adat yang berlaku. Pada sengketa tanah pelaba pura di Tampaksiring mengacu pada hukum adat dimana sanksi yang diberikan pada pelaku pensertifikatan tanah merupakan sanksi yang yang telah disepakati dan diatur dalam hukum adat setempat. Karena hukum adat di Tampaksiring sangat dihormati dan dijunjung tinggi oleh seluruh masyarakat setempat sehingga pelaku sengketa bahkan tidak melakukan perlawanan.

Delik adat adalah mencerminkan kelakuan masyarakat yang dapat mengganggu kesejahteraan masyarakat di suatu wilayah adat yang mana akan mendapat ganjaran atas setiap tindakan yang dilakukan. Delik merupakan kegiatan yang dilakukan oleh suatu individu atau sekelompok orang yang melanggar aturan adat dan mengganggu ketenangan wilayah adat merugikan masyarakat di wilayah tersebut dan pantas menerima sanksinya (Suwitra, 2009).

Atas dugaan kasus pensertifikatan tanah pelaba pura di Manukaya Anyar, Tampaksiring tersebut, warga Manukaya Anyar langsung menggelar paruman adat dan tidak melaporkan kasus tersebut ke jalur hukum yang dimana hasilnya warga memutuskan untuk memberikan waktu tiga bulan kepada kelarga pihak pensertifikatan tanah tersebut untuk segera membongkar bangunan rumah di atas lahan itu. Jeda waktu yang diberikan berdasarkan hasil paruman hingga batas terakhir waktu yang diberikan ternyata tidak dilakukan. Sehingga warga pun kembali menggelar paruman. Sebagaimana hasil paruman pada tanggal 3 April 2013 yaitu untuk melakukan pemagaran terhadap tanah tersebut pada hari Jumat 12 April 2013 pukul 07.30 wita. Aksi pemagaran tersebut tidak mendapatkan perlawanan dari pihak keluarga almarhum Dewa Ngakan Gede Dharma selaku pelaku pensertifikatan tanah pelaba pura. Akhirnya tanah tersebut diserahkan kembali ke pura secara sukarela karena pihak keluarga Dewa Ngakan Gede Dharma takut dengan adanya Delik Adat.

\section{SIMPULAN DAN SARAN}

\section{Simpulan}

Berdasarkan hasil analisis data dapat disimpulkan bahwa eksistensi tanah milik pura yaitu dengan adanya UUPA, SK yang mengatur tentang pura telah ditunjuk sebagai salah satu badan hukum bersifat keagamaan sehingga dapat mempunyai kepemilikan terhadap tanah serta dikuatkan oleh Perda Nomor 4 Tahun 2019 tentang Desa Adat sehingga dengan demikian pura menjadi subyek hak milik terhadap tanah serta bisa menguasai tanah dan memiliki status hak milik. Tanah pelaba pura dapat memiliki kepastian dan perlindungan hukum dengan mendaftarkannya ke instansi terkait, yang kedua kedudukan hukum terhadap tanah pelaba pura di Desa tampaksiring merupakan hal penting yang harus diperhatikan karena masih banyak kasus yang sangketa yang terjadi di masyarakat Bali khusunya di Desa Tampaksiring. Pada sengketa tanah pelaba pura di Tampaksiring mengacu pada hukum adat dimana sanksi yang diberikan pada pelaku pensertifikatan tanah merupakan sanksi yang yang telah disepakati dan diatur dalam hukum adat setempat. Dengan adanya kedudukan hukum ini dapat memperkuat status tanah pelaba pura memiliki dasar hukum agar tidak sembarang orang dapat mensertifikatkan tanah pelaba pura menjadi milik pribadi

\section{Saran}

Dari kasus yang dianalisis dalam penelitian ini, adapun yang menjadi saran adalah diharapkan kepada pengurus atau perangkat Desa Tampaksiring agar aktif dalam mendata serta membantu mengurus tanah yang dimiliki oleh pura serta aktif menanyakan ataupun mencari tau informasi mengenai tata cara dan proses pendaftaran tanah milik pura agar segera dapat didaftarkan, yang kedua Diharapkan agar pemerintah melakukan program pendaftaran tanah ulayat yang mana belum terdaftar untuk didaftarkan agar tanah milik pura yang merupakan tanah ulayat mendapatkan kepastian serta perlindungan hukum.

\section{DAFTAR PUSTAKA}

Arba. (2012). Hukum Pertanahan Indonesia. Sinar Grafika.

Bambang, W. (2002). Penelitian Hukum dalam Praktek. Sinar Grafika.

Djamali Abdoel. (2013). Pengantar hukum Indonesia. Raja Grafindo Persada.

H, H. (2012). Pengantar Ilmu Hukum Adat Indonesia. Mandar Maju.

Made, S. I. (2009). Eksistensi Hak Penguasaan dan Pemilikan atas Tanah Adat di Bali dalam Perspektif Hukum 
Jurnal Konstruksi Hukum

Vol. 2, No. 1, 2021

Agraria Nasional. Universitas Brawijaya.

S. Hendriatiningsih, A Budhiarta, A. H. (2008). Masyarakat dan Tanah Adat di Bali. Jurnal Sosioteknologi Edisi.

Soeroso, R. (2006). Pengantar Ilmu Hukum. Sinar Grafika.

Sudantra, I. K. (2018a). Implikasi Keputusan Dari SK Menteri Terhadap Kepemilikan Tanah Desa Pekraman. Jurnal Magister Hukum Udayana, 7(4), 23-34.

Sudantra, I. K. (2018b). Implikasi Keputusan Menteri ATR/Kepala BPN Nomor 276/KEP-19.2/X/2017 Terhadap Kedudukan Tanah Milik Desa Pakraman. Jurnal Magister Hukum Udayana, 7(4), 546-564. 